\title{
Physiological indices and growth of 'Gigante Amarelo' passion fruit under salt stress and silicate fertilization
}

\author{
Genilson L. Diniz ${ }^{1}$, Reginaldo G. Nobre², Geovani S. de Lima ${ }^{1}$, Leandro de P. Souza ${ }^{3}$, \\ Hans R. Gheyi ${ }^{3} \&$ Mizael N. V. de Medeiros ${ }^{1}$ \\ ${ }^{1}$ Universidade Federal de Campina Grande/Centro de Ciências e Tecnologia Agroalimentar/Unidade Acadêmica de Ciências Agrárias. Pombal, PB, Brasil \\ E-mail: genilsondiniz02@gmail.com - ORCID: 0000-0002-2503-6080 (Corresponding author), geovani.soares@pq.cnpq.br - ORCID: 0000-0001-9960- \\ 1858; mizaeldemedeiros@hotmail.com - ORCID: 0000-0001-5021-6131 \\ ${ }^{2}$ Universidade Federal Rural do Semi-Árido/Departamento de Ciência e Tecnologia. Caraúbas, RN, Brasil. E-mail: reginaldo.nobre@ufersa.edu.br - \\ ORCID: 0000-0002-6429-1527 \\ ${ }^{3}$ Universidade Federal de Campina Grande/Centro de Tecnologia e Recursos Naturais/Programa de Pós-Graduação em Engenharia Agrícola. Campina \\ Grande, PB, Brasil. E-mail: engenheiropadua@hotmail.com - ORCID: 0000-0001-7588-2413; hans@pq.cnpq.br - ORCID: 0000-0002-1066-0315
}

\begin{abstract}
Abiotic stresses are responsible for the loss of agricultural production in different regions, especially in semiarid regions, which have long periods of drought and high evapotranspiration, leading to the use of saline water as an alternative for the expansion of irrigated areas. In this context, the objective was to evaluate the physiological indices and the growth of the 'Gigante Amarelo' passion fruit as a function of the salinity of irrigation water and fertilization with silicon. A randomized block design was used in a $5 \mathrm{x} 2$ factorial scheme, whose treatments consisted of five electrical conductivities of irrigation water - ECW $(0.3 ; 1.0 ; 1.7,2.4$ and $3.1 \mathrm{dS} \mathrm{m}^{-1}$ ) associated with two doses of silicion (150 and $300 \mathrm{~g}$ of silicon plant ${ }^{-1}$ ) with four repetitions. Salt stress causes changes in gas exchange, chlorophyll a and b synthesis and growth of 'Gigante Amarelo' passion fruit plants, 60 days after transplanting. Fertilization with silicon dose of $300 \mathrm{~g} \mathrm{plant}^{-1}$ promotes increments in $\mathrm{CO}_{2}$ assimilation rate and instantaneous water use efficiency, being able to mitigate the deleterious effects of salinity. Passion fruit plants fertilized with silicon dose of $300 \mathrm{~g} \mathrm{plant}^{-1}$ attained greater growth in stem diameter and relative growth rate in stem diameter, from 30 to 60 days after transplanting.
\end{abstract}

Key words: Passiflora edulis f. flavicarpa, salinity, silico

\section{Índices fisiológicos e crescimento do maracujazeiro 'Gigante Amarelo’ sob estresse salino e adubação silicatada}

RESUMO: Os estresses abióticos são responsáveis pela perda de produção agrícola em distintas regiões, especialmente nas regiões semiáridas, que apresentam longos períodos de estiagem e elevada evapotranspiração induzindo a utilização de águas salinas como alternativa para expansão das áreas irrigadas. Neste sentido, objetivou-se avaliar os índices fisiológicos e o crescimento do maracujazeiro 'Gigante Amarelo' em função da salinidade da água de irrigação e da adubação com silício. Utilizou-se o delineamento experimental em blocos ao acaso em esquema fatorial $5 \times 2$, cujos tratamentos foram constituídos de cinco condutividades elétricas da água de irrigação - CEa $\left(0,3 ; 1,0 ; 1,7 ; 2,4\right.$ e $\left.3,1 \mathrm{dS} \mathrm{m}^{-1}\right)$ associadas a duas doses de silicio (150 e $300 \mathrm{~g}$ de silício planta ${ }^{-1}$ ) com quatro repetições. $\mathrm{O}$ estresse salino alterou as trocas gasosas, na síntese de clorofila a e b e crescimento das plantas de maracujazeiro 'Gigante Amarelo', aos 60 dias após o transplantio. A adubação com dose de silício de $300 \mathrm{~g}_{\text {planta }}{ }^{-1}$ proporciona incrementos na taxa de assimilação de $\mathrm{CO}_{2} \mathrm{e}$ eficiência instantânea do uso da água, sendo capaz de mitigar os efeitos deletérios da salinidade. Plantas de maracujazeiro adubadas com a dose de silício de $300 \mathrm{~g}_{\text {planta }}{ }^{-1}$, atingiram maior crescimento em diâmetro do caule e na taxa de crescimento relativo em diâmetro do caule das plantas de maracujazeiro, no período de 30 a 60 dias após o transplantio.

Palavras-chave: Passiflora edulis f. flavicarpa, salinidade, silício 


\section{INTRODUCTION}

Passion fruit (Passiflora edulis f. flavicarpa) is cultivated in almost all Brazilian territory, standing out as the largest producer and consumer, and its juice is the third most produced by Brazilian agroindustries. According to data of IBGE (2017), in 2017 the national production was 293,699.535 tons in 34,672 establishments, with Bahia standing out as the main producer at the national level with 110,470.062 tons, Ceará in fourth place with 19,559.205 tons and Pernambuco occupying the sixth place with $8,168.605$ tons.

Although the semiarid region of Northeastern Brazil has favorable conditions for the cultivation of passion fruit, its production depends on the use of irrigation, due to the seasonality of the rainfalls, high rate of evapotranspiration and high temperatures, favoring water scarcity for most of the year. Salinity affects water availability due to changes in the osmotic potential of the soil solution, reducing to the point where the plant cannot absorb water and nutrients (Dias et al., 2016).

In situations of salt stress, the osmotic and ionic effects influence the development of plants, causing changes in the metabolic activities of cells and in the process of cell elongation, compromising plant growth and possibly leading to death (Taiz et al., 2017).

In order to mitigate the effects of salinity on crop development, several studies (Ashraf et al., 2010; Moussa \& Galad, 2015) were conducted using silicon as a salt stress attenuator. Silicon promotes several benefits for crops, among them: increased photosynthetic rate, decreased toxic effect of some heavy metals, associated with increased antioxidant defense capacity in the face of water deficit (Hattori et al., 2005).

In this context, the objective of this study was to evaluate the physiological indices and growth of 'Gigante Amarelo' passion fruit under irrigation with water of different salinities and silicon doses.

\section{Material ANd Methods}

The experiment was conducted under field conditions, at the Center of Sciences and Agri-Food Technology of the Federal University of Campina Grande, in the municipality of Pombal, $\mathrm{PB}$, Brazil, located at the coordinates $6^{\circ} 47^{\prime} 3^{\prime \prime} \mathrm{S}, 37^{\circ} 49^{\prime} 15^{\prime \prime} \mathrm{W}$ and altitude of $193 \mathrm{~m}$.

The experimental design adopted was randomized blocks, with treatments arranged in $5 \times 2$ factorial scheme corresponding to five electrical conductivities of irrigation water - $\operatorname{ECw}\left(0.3 ; 1.0 ; 1.7 ; 2.4\right.$ and $\left.3.1 \mathrm{dS} \mathrm{m}^{-1}\right)$ associated with two doses of silicate fertilization (150 and $300 \mathrm{~g}$ of silicon plant ${ }^{-1}$ ) with four replicates. Water salinity levels were determined based on research conducted by Andrade et al. (2018), obtained through the addition of sodium chloride $(\mathrm{NaCl})$ in water from the supply system of Pombal, $\mathrm{PB}$, Brazil ( $\mathrm{ECw}=0.3 \mathrm{dS} \mathrm{m} \mathrm{m}^{-1}$ ) according to the relationship between EC and the concentration of salts $\left(\mathrm{mg} \mathrm{L}^{-1}=640 \times \mathrm{ECw}\right)$ (Richards, 1954).

'Gigante Amarelo' passion fruit seedlings were produced in plastic bags with dimensions of $15 \times 20 \mathrm{~cm}$, filled with substrate containing soil, sand and decomposed cattle manure at proportion of $2: 1: 1$, respectively on volume basis, sowing two seeds per bag, which were irrigated with water of lowest salinity level $\left(\mathrm{ECw}=0.3 \mathrm{dS} \mathrm{m}^{-1}\right)$. After seedling emergence, thinning was performed leaving only one plant per container, when they reached $10 \mathrm{~cm}$ in height.

At 60 days after sowing (DAS), the seedlings were transplanted to drainage lysimeters (polyethylene buckets) with capacity of $100 \mathrm{~L}$, filled with a layer of $0.5 \mathrm{~kg}$ of crushed stone followed by $100 \mathrm{~kg}$ of soil material of a Neossolo (Entisol) with loamy sand texture, from the rural area of the municipality of São Domingos, PB (properly pounded to break up clods and homogenized), whose chemical and physical characteristics (Table 1) were obtained according to the methodology proposed by Teixeira et al. (2017).

The lysimeters were drilled at the base to allow drainage and coupled to a transparent drain with diameter of $4 \mathrm{~mm}$. The end of the drain inside the pot was wrapped with a non-woven geotextile (Bidim OP 30) to prevent clogging by soil material. Below each drain, a plastic bottle was placed to collect drained water and estimate water consumption by the plant.

Soil moisture content was elevated to field capacity using water with the lowest salinity level $\left(\mathrm{ECw}=0.3 \mathrm{dS} \mathrm{m}^{-1}\right)$. In order to facilitate the acclimation process, after transplanting the plants were irrigated using water with ECw of $0.3 \mathrm{dS} \mathrm{m}^{-1}$ until 29 days after transplanting (DAT). Saline waters began to be applied from 30 DAT.

Irrigation was manually performed every day using water from the respective treatment and based on the drainage lysimetry process (Bernardo et al., 2006). The volume applied in each irrigation was determined by the difference between volume applied and volume drained in the previous day, plus a leaching fraction of 0.15 , aiming to avoid excessive accumulation of salts in the soil, applied every 20 days and following the electrical conductivity data of the drained water.

Nitrogen and potassium fertilization was performed monthly, according to Santos (2001), using ammonium sulfate and potassium chloride as sources, respectively, for potassium fertilization, the content of the element applied via potassium

Table 1. Physical and chemical characteristics of the soil used to produce seedlings and grow 'Gigante Amarelo' passion fruit plants

\begin{tabular}{|c|c|c|c|c|c|c|c|c|c|}
\hline \multicolumn{10}{|c|}{ Chemical characteristics } \\
\hline \multirow{2}{*}{$\begin{array}{c}\mathrm{pH}\left(\mathrm{H}_{2} \mathrm{O}\right) \\
(1: 2.5)\end{array}$} & \multirow{2}{*}{$\begin{array}{c}\mathrm{OM} \\
\left(\text { dag kg }^{-1}\right)\end{array}$} & \multirow{2}{*}{$\begin{array}{c}\mathbf{P} \\
(\mathrm{mg} \mathrm{kg})\end{array}$} & $\mathrm{K}^{+}$ & $\mathrm{Na}^{+}$ & $\mathrm{Ca}^{2+}$ & $\mathrm{Mg}^{2+}$ & $\mathrm{H}^{+}+\mathrm{Al}^{3+}$ & \multirow{2}{*}{$\begin{array}{l}\text { ESP } \\
(\%)\end{array}$} & \multirow{2}{*}{$\begin{array}{c}\text { ECse } \\
\text { (dS m }{ }^{-1} \text { ) }\end{array}$} \\
\hline & & & \multicolumn{5}{|c|}{$\left(\mathrm{cmol}_{\mathrm{c}} \mathrm{kg}^{-1}\right)$} & & \\
\hline 7.00 & 3.80 & 11.99 & 0.38 & 0.09 & 2.42 & 5.84 & 0.00 & 1.05 & 0.75 \\
\hline \multicolumn{10}{|c|}{ Physical characteristics } \\
\hline \multicolumn{3}{|c|}{ Size fraction $\left.(\mathrm{g} \mathrm{kg})^{-1}\right)$} & \multirow{2}{*}{$\begin{array}{c}\text { Textural } \\
\text { class }\end{array}$} & Water & it (kPa) & \multirow{2}{*}{ AW } & \multirow{2}{*}{$\begin{array}{c}\text { Total porosity } \\
\text { (\%) }\end{array}$} & AD & PD \\
\hline Sand & Silt & Clay & & $33.42^{1}$ & 1519.5 & & & \multicolumn{2}{|c|}{$\left(\mathrm{kg} \mathrm{dm}^{-3}\right)$} \\
\hline 853.00 & 130.70 & 16.30 & LS & 11.60 & 4.23 & 6.93 & 47.23 & 1.50 & 2.69 \\
\hline
\end{tabular}

$\mathrm{pH}$ - Hydrogen potential, OM - Organic matter: Walkley-Black Wet Digestion; $\mathrm{Ca}^{2+}$ and $\mathrm{Mg}^{2+}$ extracted with $1 \mathrm{M} \mathrm{KCl}$ at $\mathrm{pH} 7.0 ; \mathrm{Na}^{+}$and $\mathrm{K}^{+}$extracted with $1 \mathrm{M} \mathrm{NH} \mathrm{OAc} \mathrm{at} \mathrm{pH} 7.0$ $\mathrm{Al}^{3+}+\mathrm{H}^{+}$extracted with $0.5 \mathrm{M} \mathrm{CaOAc}$ at $\mathrm{pH}$ 7.0; ESP - Exchangeable sodium percentage; ECse - Electrical conductivity of the saturation extract; LS - Loamy Sand; ${ }^{1,2}$ referring to the limits of field capacity and permanent wilting point, respectively; AW - Available water; AD - Apparent density; PD - Particle density 
silicate was taken into account. Applications were carried out around the plant, maintaining a distance of approximately $10 \mathrm{~cm}$ from the plant collar.

Application of silicon doses started at 30 DAT and were performed at 10-day intervals, totaling four applications until 60 DAT, according to the treatments. The different doses of silicate fertilization were diluted separately in water from the respective treatment, using potassium silicate as source of silicon, composed of multiple minerals (selenium, vanadium, calcium, zinc, phosphorus among several oligo-elements, with $50 \%$ of $\mathrm{SiO}_{2}$ and $4 \%$ of $\mathrm{K}_{2} \mathrm{O}$ ). Silicon doses were determined considering $\mathrm{SiO}_{2}$ contents and $\mathrm{K}$ supplied was discounted from the $\mathrm{K}$ dose.

Micronutrients were applied weekly through the leaves, using Quimifol (solution containing nitrogen, boric acid, lignosulfonates, amino acids, polysaccharides, leonardite and preservative) at ratio of $0.5 \mathrm{~g} \mathrm{~L}^{-1}$ (Cavalcanti, 2008). During the experimental period, the cultural practices and phytosanitary treatments recommended for the crop were performed.

The adopted spacing was $3 \mathrm{~m}$ between rows and $2 \mathrm{~m}$ between plants, using the vertical trellis system with smooth wire $\mathrm{n}^{\circ} 14$. A wire string was used to conduct the plant to the trellis. When the plants reached $10 \mathrm{~cm}$ above the trellis, the apical bud was removed, aiming at the production of the secondary branches, of which only two were selected and trained one to each side until reaching the length of $1.0 \mathrm{~m}$.

After the secondary branches reached half the spacing between plants $(1.0 \mathrm{~m})$, a new pruning of the apical bud was performed, aiming to promote the production of tertiary branches, which formed a curtain. During the experimental period, tendrils and unwanted branches were eliminated in order to favor crop development.

Passion fruit growth was evaluated at 30 and 60 days after the beginning of the treatments, by determining stem diameter (SD), which was measured at $10 \mathrm{~cm}$ from the soil using a caliper. These data were used to obtain the absolute (AGRsd) and relative growth rate of stem diameter (RGRsd), which were evaluated for the period from 30 to 60 DAT, adapting to the procedures contained in Benincasa (2003), according to Eqs. 1 and 2.

$$
\begin{gathered}
\text { AGRsd }=\frac{\left(\mathrm{SD}_{2}-\mathrm{SD}_{1}\right)}{\left(\mathrm{T}_{2}-\mathrm{T}_{1}\right)} \\
\text { RGRsd }=\frac{\left(\ln \mathrm{SD}_{2}-\ln \mathrm{SD}_{1}\right)}{\left(\mathrm{T}_{2}-\mathrm{T}_{1}\right)}
\end{gathered}
$$

where:

AGRsd - absolute growth rate of stem diameter, $\mathrm{mm} \mathrm{d}^{-1}$;

$\mathrm{SD}_{1}$ - stem diameter, $\mathrm{mm}$, at time $\mathrm{t}_{1}$;

$\mathrm{SD}_{2}$ - stem diameter, $\mathrm{mm}$, at time $\mathrm{t}_{2}$;

RGRsd - relative growth rate of stem diameter, $\mathrm{mm} \mathrm{mm}^{-1} \mathrm{~d}^{-1}$; and,

ln - natural logarithm.

At 60 days after transplanting, gas exchange was determined based on stomatal conductance ( $\mathrm{gs}-\mathrm{mol} \mathrm{H}_{2} \mathrm{O} \mathrm{m}^{-2} \mathrm{~s}^{-1}$ ), transpiration ( $\left.\mathrm{E}-\mathrm{mmol} \mathrm{H}_{2} \mathrm{O} \mathrm{m}^{-2} \mathrm{~s}^{-1}\right), \mathrm{CO}_{2}$ assimilation rate $\left(\mathrm{A}-\mu \mathrm{mol} \mathrm{m} \mathrm{m}^{-2} \mathrm{~s}^{-1}\right)$ and intercellular $\mathrm{CO}_{2}$ concentration $\left(\mathrm{Ci}-\mu \mathrm{mol} \mathrm{mol}{ }^{-1}\right)$. These data were then used to determine instantaneous water use efficiency (WUEi) $\left(\mathrm{A} / \mathrm{E}-\mu \mathrm{mol} \mathrm{m} \mathrm{m}^{-2} \mathrm{~s}^{-1}\right.$ $\left.\left(\mathrm{mmol} \mathrm{H}_{2} \mathrm{O} \mathrm{m}^{-2} \mathrm{~s}^{-1}\right)^{-1}\right)$ and instantaneous carboxylation efficiency (CEi) $\left(\mathrm{A} / \mathrm{Ci}-\mu \mathrm{mol} \mathrm{m} \mathrm{m}^{-2} \mathrm{~s}^{-1}\left(\mu \mathrm{mol} \mathrm{mol} \mathrm{m}^{-1}\right)^{-1}\right)$ under photosynthetic photon flux density of $1,200 \mu \mathrm{mol} \mathrm{m}^{-2} \mathrm{~s}^{-1}$, using an infrared gas analyzer - IRGA (Infra-Red Gas Analyser, LCpro - SD model, ADC Bioscientific, UK).

The contents of chlorophyll a, chlorophyll $b$ and carotenoids ( $\mathrm{mg} \mathrm{g}^{-1}$ of fresh matter - FM) were determined by following the laboratory method developed by Arnon (1949), according to Eqs. 3, 4 and 5:

$$
\begin{gathered}
\text { Chlorophyll } \mathrm{a}=(12.7 \times \mathrm{A} 663-2.69 \times \mathrm{A} 645) \\
\text { Chlorophyll } \mathrm{b}=(22.9 \times \mathrm{A} 645-4.68 \times \mathrm{A} 663) \\
\text { Carotenoids }=\frac{(1000 \times \mathrm{A} 470-1.82 \mathrm{Chl} \mathrm{a}-85.02 \mathrm{Chl} \mathrm{b})}{198}
\end{gathered}
$$

At 60 DAT, the protoplasmic content in the cell membrane was determined according to the methodology described by Campos \& Thi (1997), as shown in Eq. 6:

$$
\mathrm{PC}=\frac{\mathrm{Ci}}{\mathrm{Cf}} 100
$$

where:

PC - protoplasmic content, \%;

$\mathrm{Ci}$ - initial electrical conductivity, $\mathrm{dS} \mathrm{m}^{-1}$; and,

Cf - final electrical conductivity, $\mathrm{dS} \mathrm{m} \mathrm{m}^{-1}$.

The data referring to the measured variables were subjected to the $\mathrm{F}$ test at $\mathrm{p} \leq 0.05$ and $\mathrm{p} \leq 0.01$. When there was a significant effect of the treatments, the means of the variables were subjected to Tukey test at $\mathrm{p} \leq 0.05$ for silicon doses and polynomial regression for salinity concentrations.

\section{Results AND Discussion}

The interaction between salinity levels (SL) and silicon doses (SD) in the experimental plots did not have a significant effect on the gas exchange variables, demonstrating that these factors do not interfere jointly in passion fruit. However, there was significant effect for the single factors; stomatal conductance (gs), intercellular $\mathrm{CO}_{2}$ concentration (Ci), transpiration (E) and instantaneous water use efficiency (WUEi) were significantly affected by salinity levels, while stomatal conductance (gs), $\mathrm{CO}_{2}$ assimilation rate $(\mathrm{A})$ and instantaneous water use efficiency (WUEi) differed statistically with the application of silicon doses (Table 2).

By analyzing the silicon doses alone, it was found that the use of the highest concentration ( $300 \mathrm{~g} \mathrm{Si} \mathrm{plant}^{-1}$ ) led to a $22.22 \%$ reduction in stomatal conductance (gs) (Table 2), but promoted increments in $\mathrm{CO}_{2}$ assimilation rate (A) and instantaneous water use efficiency (WUEi), corresponding to 21.43 and $19.51 \%$, 
Table 2. Summary of the analysis of variance for stomatal conductance (gs - $\mathrm{mol} \mathrm{H}_{2} \mathrm{O} \mathrm{m}^{-2} \mathrm{~s}^{-1}$ ), intercellular $\mathrm{CO}_{2}$ concentration $\left(\mathrm{Ci}-\mu \mathrm{mol} \mathrm{mol}{ }^{-1}\right)$, transpiration $\left(\mathrm{E}-\mathrm{mmol} \mathrm{H}_{2} \mathrm{O} \mathrm{m}^{-2} \mathrm{~s}^{-1}\right), \mathrm{CO}_{2}$ assimilation rate $\left(\mathrm{A}-\mu \mathrm{mol} \mathrm{m} \mathrm{m}^{-2} \mathrm{~s}^{-1}\right)$, instantaneous water use efficiency (WUEi $\left.-\mu \mathrm{mol} \mathrm{m}^{-2} \mathrm{~s}^{-1}\left(\mathrm{mmol} \mathrm{H}_{2} \mathrm{O} \mathrm{m}^{-2} \mathrm{~s}^{-1}\right)^{-1}\right)$ and instantaneous carboxylation efficiency $\left(\mathrm{CEi}-\mu \mathrm{mol} \mathrm{m}^{-2} \mathrm{~s}^{-1}\left(\mu \mathrm{mol} \mathrm{mol}^{-1}\right)^{-1}\right)$ in ${ }^{`} \mathrm{Gigante}$ Amarelo' passion fruit cultivated under different levels of irrigation water salinity and doses of silicon, at 60 days after transplanting

\begin{tabular}{|c|c|c|c|c|c|c|c|}
\hline \multirow{2}{*}{ Source of variation } & \multirow{2}{*}{ DF } & \multicolumn{6}{|c|}{ Mean squares } \\
\hline & & gs & $\overline{\mathrm{Ci}}$ & $E$ & $\bar{A}$ & WUEi & CEF \\
\hline Saline levels (SL) & 4 & $0.003^{* *}$ & $5365.14^{* *}$ & $1.85^{\star *}$ & $49.24^{\mathrm{ns}}$ & $2.61^{*}$ & $0.0001^{\mathrm{ns}}$ \\
\hline Linear regression & 1 & $0.009^{\star *}$ & $20779.32^{\star \star}$ & $6.01^{\star *}$ & $25.02^{\text {ns }}$ & $9.43^{\star \star}$ & $0.0001^{\mathrm{ns}}$ \\
\hline Quadratic regression & 1 & $0.002^{\star}$ & $240.20^{\text {ns }}$ & $0.85^{\mathrm{ns}}$ & $28.62^{\text {ns }}$ & $0.92^{\text {ns }}$ & $0.0001^{\mathrm{ns}}$ \\
\hline Silicon doses (SD) & 1 & $0.002^{\star *}$ & $846.30^{\text {ns }}$ & $0.01^{\text {ns }}$ & $3483.44^{\star *}$ & $3.97^{\star}$ & $0.0001^{\text {ns }}$ \\
\hline Interaction (SL x SD) & 4 & $0.0005^{\mathrm{ns}}$ & $826.08^{\text {ns }}$ & $0.19^{\text {ns }}$ & $147.86^{\text {ns }}$ & $0.26^{\text {ns }}$ & $0.0003^{\text {ns }}$ \\
\hline Blocks & 3 & $0.0013^{\text {ns }}$ & $604.66^{\text {ns }}$ & $0.85^{\text {ns }}$ & $356.14^{\text {ns }}$ & $2.50^{\text {ns }}$ & $0.0004^{\mathrm{ns}}$ \\
\hline Residue & 27 & 0.00054 & 1125.46 & 0.27 & 364.67 & 0.90 & 0.00047 \\
\hline \multirow[t]{2}{*}{ CV (\%) } & & 28.18 & 15.57 & 23.26 & 19.80 & 26.26 & 43.00 \\
\hline & & \multicolumn{6}{|c|}{ Mean } \\
\hline \multicolumn{8}{|l|}{ Silicon doses } \\
\hline $150 \mathrm{~g}$ & & $0.09 a$ & $220.13 a$ & $2.28 \mathrm{a}$ & $87.11 \mathrm{~b}$ & $3.28 b$ & $0.04 \mathrm{a}$ \\
\hline $300 \mathrm{~g}$ & & $0.07 \mathrm{~b}$ & $210.93 \mathrm{a}$ & $2.25 \mathrm{a}$ & $105.78 \mathrm{a}$ & $3.92 \mathrm{a}$ & $0.05 \mathrm{a}$ \\
\hline
\end{tabular}

respectively. The use of silicon fertilization promotes anatomical changes in passion fruit, such as the increase in the thickness of the palisade parenchyma, which is related to the functionality of the stomata (Costa et al., 2016). The reduction observed in gs may be related to the modification of leaf architecture, but it did not cause damage to $\mathrm{CO}_{2}$ assimilation.

On the other hand, the increase obtained in the $\mathrm{CO}_{2}$ assimilation rate and instantaneous water use efficiency may be related to the deposition of silicon on leaf wall, which increases the resistance and hardness of cell walls, reducing cuticular transpiration and consequently increasing the efficiency in water use and photosynthesis (Jesus et al., 2018).
As the salinity levels of irrigation water increased, gs decreased linearly by $14.57 \%$ per unit increment in ECw, i.e., plants grown under ECw of $3.1 \mathrm{dS} \mathrm{m}^{-1}$ had a $42.67 \%$ reduction in gs compared to those under the lowest level of water salinity $\left(0.3 \mathrm{dS} \mathrm{m}^{-1}\right)$ (Figure 1A). Due to the excess of salts in the root zone, there may be a reduction in stomatal opening, in an attempt to reduce leaf transpiration (Taiz et al., 2017). Similar results were found by Freire et al. (2014) in yellow passion fruit under water salinity, in an experiment conducted in an open orchard in the state of Paraíba, using irrigation water with salinity of 0.50 and $4.50 \mathrm{dS} \mathrm{m}^{-1}$, showing inhibition of photochemical activity of photosystem II and net photosynthesis of plants.
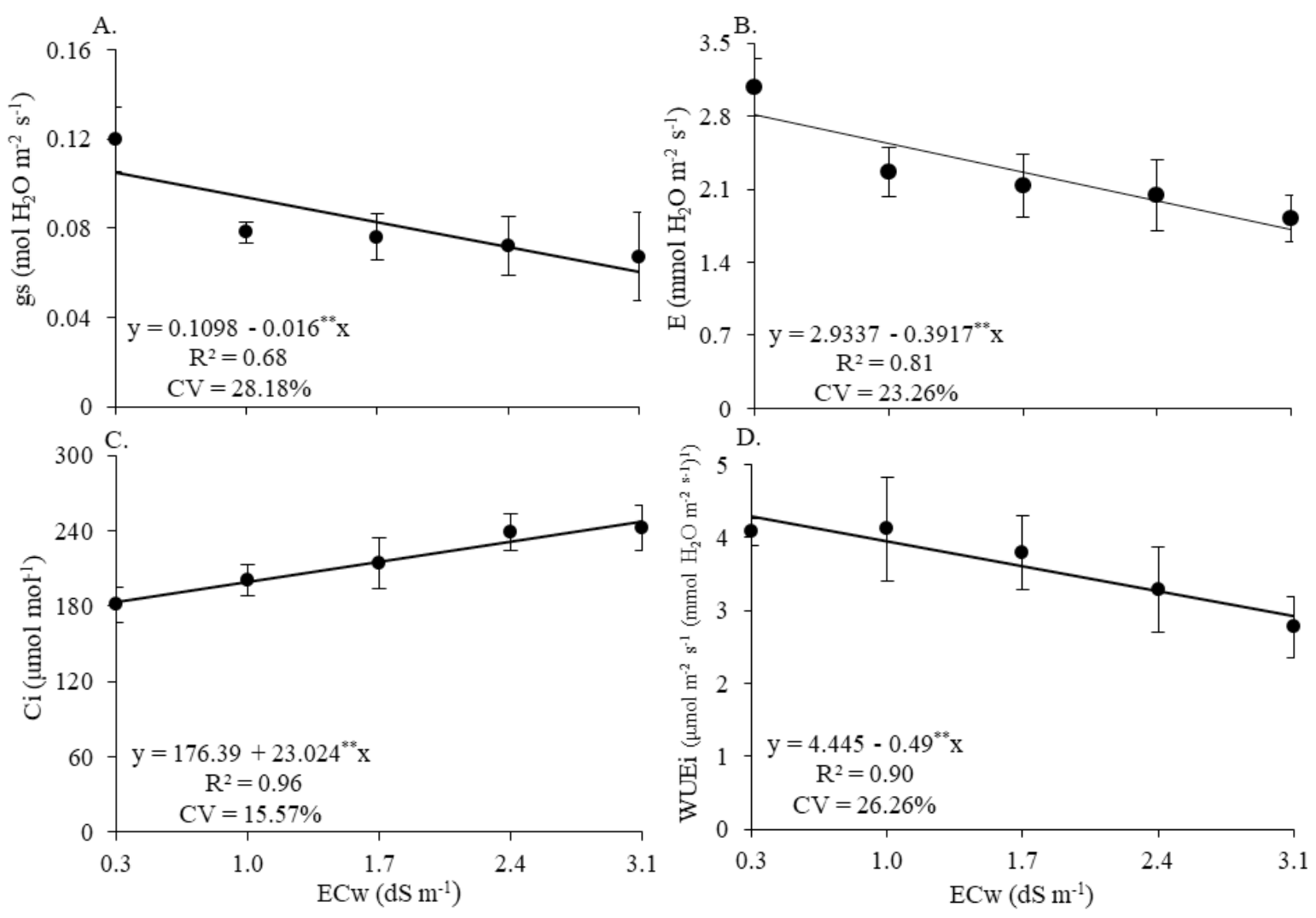

${ }^{*}$ - Significant at $\mathrm{p} \leq 0.01$; Vertical bars represent the standard error of the mean $(n=4)$

Figure 1. Stomatal conductance - gs (A), transpiration - E (B), intercellular $\mathrm{CO}_{2}$ concentration - Ci (C) and instantaneous water use efficiency - WUEi (D) of 'Gigante Amarelo’ passion fruit as a function of irrigation water salinity - ECw, at 60 days after transplanting 
Salinity in irrigation water also caused reduction in transpiration rate, as well as in the instantaneous water use efficiency, with unit losses of $13.35 \%$ and $11.02 \%$, respectively (Figures 1B and D). Probably, passion fruit plants under salt stress conditions reduced stomatal conductance and transpiration, in order to increase their water use efficiency and avoid excessive dehydration. However, the reduction observed in WUEi probably occurred because the plant, even under stress conditions, continued photosynthesizing normally, maintaining the production of sugars (Silva et al., 2011; Sousa et al., 2019).

Irrigation with saline waters promoted a linear increase in $\mathrm{Ci}$, equal to $13.06 \%$ per unit increase in $\mathrm{ECw}$. When comparing the plants that were irrigated using water with ECw of 0.3 and $3.1 \mathrm{dS} \mathrm{m}^{-1}$, there was an increase of 247.76 $\mu \mathrm{mol} \mathrm{mol}{ }^{-1}$, which corresponded to $35.17 \%$ (Figure 1C). This result demonstrates that there was a limitation in stomatal opening, but it did not restrict the entry of $\mathrm{CO}_{2}$ into the cell, because the reduction in conductance led to a decrease in the absorption of water and salts from the soil solution, without compromising photosynthetic activity, due to the increase in $\mathrm{CO}_{2}$ concentration, which may indicate that the carbon that entered the cell was not assimilated, with no significant effect of water salinity on photosynthesis rate and instantaneous carboxylation efficiency in this study (Silva et al., 2011).

For the photosynthetic pigments, there was no interactive effect of the factors studied. However, salinity levels of irrigation water significantly influenced chlorophyll a, carotenoids and protoplasmic content, while the application of silicon doses significantly influenced chlorophyll b and carotenoids of passion fruit plants (Table 3).

The highest concentrations of chlorophyll $b$ and carotenoids (CAR) in passion fruit plants were observed in plants fertilized with the silicon dose of $300 \mathrm{~g} \mathrm{plant}^{-1}$, which promoted increments of 20.61 and $10.78 \%$, respectively, compared to plants fertilized with the silicon dose of $150 \mathrm{~g} \mathrm{plant}^{-1}$ (Table 3).

Silicon supply increases the concentrations of chlorophyll $b$ and carotenoids, as well as the photosynthetic rate of plants (Guerra et

Table 3. Summary of the analysis of variance and means of chlorophyll a (CHL a - $\mathrm{mg} \mathrm{g}^{-1} \mathrm{FM}$ ), chlorophyll b (CHL b $\mathrm{mg} \mathrm{g}^{-1} \mathrm{FM}$ ), carotenoids (CAR - $\mathrm{mg} \mathrm{g}^{-1} \mathrm{FM}$ ) and protoplasmic content (PC - \%) in 'Gigante Amarelo' passion fruit cultivated under different salinity levels of irrigation water and silicon doses, at 60 days after transplanting

\begin{tabular}{|c|c|c|c|c|c|}
\hline \multirow{2}{*}{$\begin{array}{c}\text { Source } \\
\text { of variation }\end{array}$} & \multirow{2}{*}{ DF } & \multicolumn{4}{|c|}{ Mean squares } \\
\hline & & CHL a & CHL b & CAR & PC \\
\hline Saline levels (SL) & 4 & $2.32^{\star \star}$ & $0.45^{\mathrm{ns}}$ & $10031.23^{\star}$ & $27.92^{\star *}$ \\
\hline Linear regression & 1 & $8.77^{\star \star}$ & $1.62^{\mathrm{ns}}$ & $37791.94^{\star \star}$ & $105.40^{* *}$ \\
\hline Quadratic regression & 1 & $0.06^{\text {ns }}$ & $0.06^{n s}$ & $2292.18^{\text {ns }}$ & $0.41^{\mathrm{ns}}$ \\
\hline Silicon doses (SD) & 1 & $0.01^{\mathrm{ns}}$ & $4.11^{\star *}$ & $77494.56^{\star \star}$ & $12.76^{\text {ns }}$ \\
\hline Interaction (SL x SD) & 4 & $0.41^{\mathrm{ns}}$ & $1.41^{\mathrm{ns}}$ & $14671.47^{\text {ns }}$ & $1.29^{\mathrm{ns}}$ \\
\hline Blocks & 3 & $0.25^{\mathrm{ns}}$ & $1.49^{*}$ & $9098.16^{\text {ns }}$ & $4.21^{\mathrm{ns}}$ \\
\hline Residue & 27 & 0.28 & 0.49 & 2675.35 & 3.98 \\
\hline \multirow[t]{2}{*}{ CV (\%) } & & 14.97 & 15.22 & 10.98 & 18.07 \\
\hline & & \multicolumn{4}{|c|}{ Mean } \\
\hline Silicon doses & & & & & \\
\hline $150 \mathrm{~g}$ & $3.54 \mathrm{a}$ & $4.29 b$ & $426.93 \mathrm{~b}$ & $10.48 b$ & $3.54 \mathrm{a}$ \\
\hline $300 \mathrm{~g}$ & $3.58 \mathrm{a}$ & $4.93 \mathrm{a}$ & $514.96 \mathrm{a}$ & $11.61 \mathrm{a}$ & $3.58 \mathrm{a}$ \\
\hline
\end{tabular}

al., 2014). The silicon absorbed by the plants is deposited below the epidermal cuticle, forming a double layer of silica in the cells. This incorporation causes changes in the architecture of these plants, which keep the leaves more upright, improving the interception of sunlight and, therefore, photosynthesis.

Chlorophyll a synthesis showed a decreasing linear behavior as the salinity levels of irrigation water increased, equal to $10.87 \%$ per unit increase in ECw (Figure 2A). Comparatively, there was a reduction from 4.22 to $2.89 \mathrm{mg} \mathrm{g}^{-1} \mathrm{FM}$ in the range from 0.3 to $3.1 \mathrm{dS} \mathrm{m}^{-1}$. The reduction in chlorophyll a contents, according to Munns \& Tester (2008), is the result of imbalances in physiological and biochemical activities promoted by the content of salts in the root zone beyond that tolerated by the crop, which stimulates the activity of chlorophyllase, an enzyme responsible for the degradation of chlorophyll, inducing the destruction of chloroplasts.
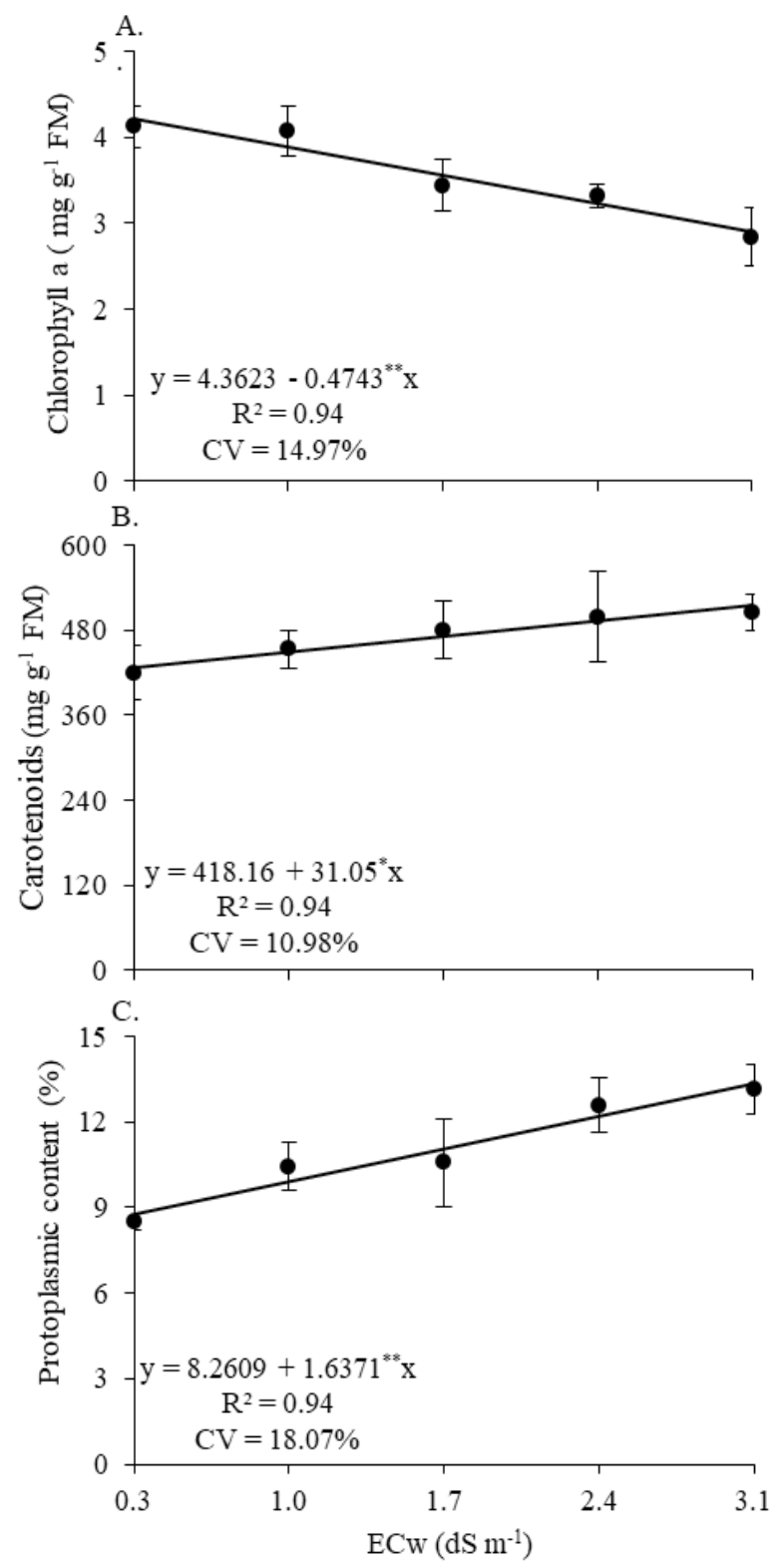

*, ${ }^{*}$ - Significant at $\mathrm{p} \leq 0.05$ and $\mathrm{p} \leq 0.01$; Vertical bars represent the standard error of the mean $(\mathrm{n}=4)$

Figure 2. Chlorophyll a (A), carotenoids (B) and protoplasmic content (C) in 'Gigante Amarelo' passion fruit as a function of the electrical conductivity of irrigation water - ECw, at 60 days after transplanting 
Similar results were reported by Wanderley et al. (2018), who evaluated the contents of photosynthetic pigments in passion fruit as a function of irrigation water salinity in the seedling formation stage and found a decrease in chlorophyll a content of $8.22 \%$ per unit increase in ECw.

Regarding the carotenoid content (Figure 2B), there was an increase of $7.42 \%$ per unit increase in $\mathrm{ECw}$, i.e., passion fruit plants irrigated with $3.1 \mathrm{dS} \mathrm{m}^{-1}$ water increased by $20.61 \%$ the synthesis of CAR compared to those that were irrigated with $0.3 \mathrm{dS} \mathrm{m}^{-1}$ water. Carotenoids can act in some situations as antioxidant agents, mitigating the deleterious effect of salinity, by attenuating photooxidative damage, which explains the increase of this pigment (Ashraf \& Harris 2013; Lima et al., 2017).

The salinity levels of irrigation water increased the protoplasmic content of passion fruit plants, by $19.82 \%$ per unit increase in ECw (Figure 2C). For being a salinity-sensitive crop, the increase of salts in irrigation water caused repture in the cell membrane, evidenced by the gradual increase in protoplasmic content, which indicates the release of ions from the cell membrane caused by excess salts (Rutschow et al., 2011). Corroborating the present study, Santos et al. (2018) in a study with yellow passion fruit seedlings under irrigation using water with salinity from 0.3 to $4.3 \mathrm{dS} \mathrm{m}^{-1}$, verified a $29 \%$ increase in protoplasmic content between 0.3 and $4.3 \mathrm{dS} \mathrm{m}^{-1}$.

Regarding the growth variables of passion fruit, the analysis of variance showed that there was no significant effect of the interaction between factors (water salinity levels $\mathrm{x}$ silicon doses) on any of the variables analyzed (Table 4). Irrigation water salinity significantly affected the stem diameter (SD) and absolute growth rate of stem diameter (AGRsd) of passion fruit plants. Silicon doses significantly influenced the relative growth rate of stem diameter (RGRsd) in the period between 30 and 60 DAT.

According to the means comparison test (Table 4), passion fruit plants fertilized with the highest dose of silicon (300 g plant $\left.^{-1}\right)$ showed increments in SD and RGRsd of 8.07 and 50\%, respectively, compared to those that received the lowest dose

Table 4. Summary of the analysis of variance and means of stem diameter $(\mathrm{SD}-\mathrm{mm})$ at 60 days after transplantingDAT, absolute (AGRsd $-\mathrm{mm} \mathrm{d}^{-1}$ ) and relative growth rate of stem diameter (RGRsd - $\mathrm{mm} \mathrm{mm}^{-1} \mathrm{~d}^{-1}$ ) in 'Gigante Amarelo' passion fruit, in the period between 30 and 60 DAT subjected to irrigation water salinity and silicon doses

\begin{tabular}{|c|c|c|c|c|}
\hline \multirow{2}{*}{$\begin{array}{c}\text { Source } \\
\text { of variation }\end{array}$} & \multirow{2}{*}{ DF } & \multicolumn{3}{|c|}{ Mean squares } \\
\hline & & SD & AGRsd & RGRsd \\
\hline Saline levels (SL) & 4 & $5.87^{\star \star}$ & $0.0016^{\star \star}$ & $0.000007^{\mathrm{ns}}$ \\
\hline Linear regression & 1 & $21.97^{\star \star}$ & $0.005^{\star *}$ & $0.00002^{\star *}$ \\
\hline Quadratic regression & 1 & $0.42^{\mathrm{ns}}$ & $0.0008^{*}$ & $0.000001^{\mathrm{ns}}$ \\
\hline Silicon doses (SD) & 1 & $8.22^{\star \star}$ & $0.000008^{\text {ns }}$ & $0.00004^{\star \star}$ \\
\hline Interaction (SL x SD) & 4 & $0.56^{\mathrm{ns}}$ & $0.003^{\text {ns }}$ & $0.000004^{\mathrm{ns}}$ \\
\hline Blocks & 3 & $0.72^{\text {ns }}$ & $0.0001^{\text {ns }}$ & $4.50 \times 10^{-7 n s}$ \\
\hline Residue & 27 & 0.46 & 0.0001 & 0.000003 \\
\hline \multirow[t]{2}{*}{ CV (\%) } & & 5.82 & 24.94 & 32.54 \\
\hline & \multicolumn{4}{|c|}{ Mean } \\
\hline \multicolumn{5}{|l|}{ Silicon doses } \\
\hline $150 \mathrm{~g}$ & & $11.28 b$ & $0.048 a$ & $0.004 \mathrm{~b}$ \\
\hline $300 \mathrm{~g}$ & & $12.19 \mathrm{a}$ & $0.047 \mathrm{a}$ & $0.006 \mathrm{a}$ \\
\hline
\end{tabular}

$\mathrm{ns}, *, * *$ - Not significant, significant at $\mathrm{p} \leq 0.05$ and $\mathrm{p} \leq 0.01$, respectively, by $\mathrm{F}$ test; Mean followed by different letters indicate significant difference between treatments by Tukey test $(\mathrm{p} \leq 0.05)$ of silicate (150 g plant $\left.{ }^{-1}\right)$. As potassium silicate was used as a source of silicon and it has a slow release of the mineral, a large amount was necessary to meet the needs of plants and its use in large quantities caused stem elongation, because of the benefits of silicon for photosynthesis and consequently for growth (Marschner, 1995).

Costa et al. (2016), while studying the action of silicon on the growth of passion fruit plants, found that this element increased stem diameter up to the concentration of 0.20 g per pot, promoting greater plant growth.

SD and AGRsd decreased by 16.39 and $48.40 \%$, relatively, between the highest and lowest levels of salinity, respectively (Figures $3 \mathrm{~A}$ and $\mathrm{B}$ ). Under salt stress conditions, plants reduce growth due to the energy consumption for the synthesis of osmotically active organic compounds necessary for compartmentalization processes in the regulation of ion transport (Torres et al., 2014).

Bezerra et al. (2016) also observed reductions in the growth rate of passion fruit plants as a function of salinity of irrigation water. Andrade et al. (2018) observed a 31\% decrease in stem diameter in passion fruit seedlings while using irrigation water of salinity between 0.2 and $6.2 \mathrm{dS} \mathrm{m}^{-1}$.
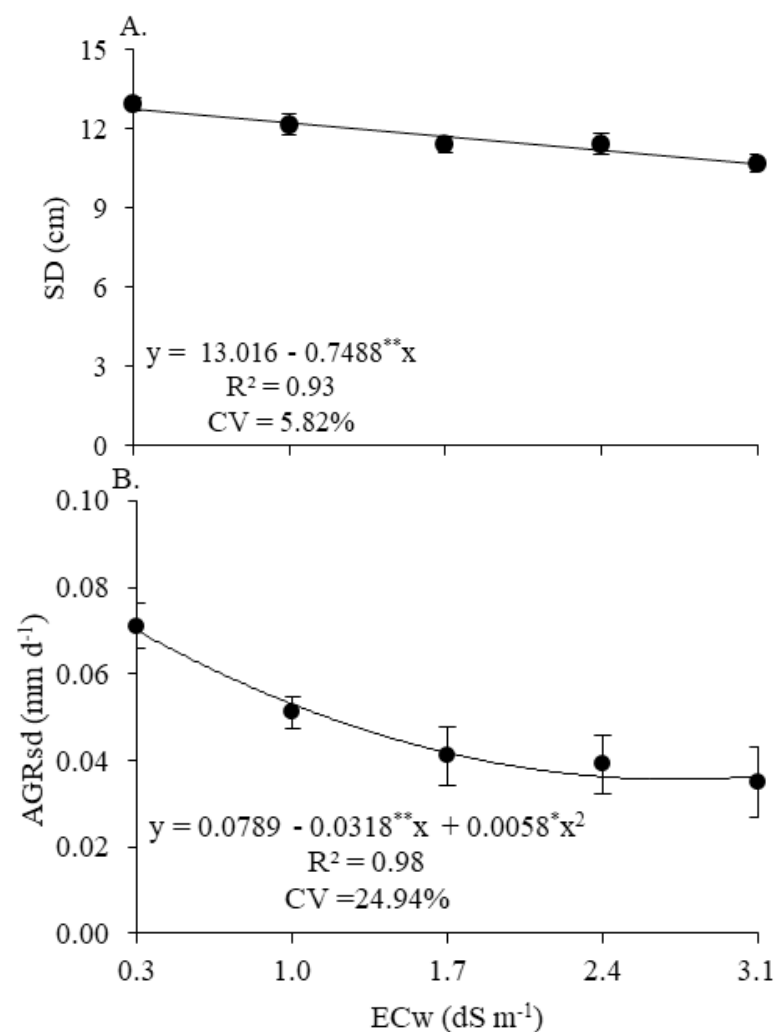

*, ** - Significant at $\mathrm{p} \leq 0.05$ and $\mathrm{p} \leq 0.01$; Vertical bars represent the standard error of the mean $(n=4)$

Figure 3. Stem diameter - SD (A) at 60 days after transplanting - DAT and absolute growth rate of stem diameter - AGRsd (B) of 'Gigante Amarelo' passion fruit as a function of the electrical conductivity of irrigation water - ECw, in the period between 30 and 60 DAT

\section{Conclusions}

1. Salt stress affects the gas exchange, chlorophyll a synthesis, carotenoids and protoplasmic content and growth of 'Gigante Amarelo' passion fruit plants, at 60 days after transplanting. 
2. Fertilization with silicon dose of $300 \mathrm{~g}_{\text {plant }}{ }^{-1}$ promotes increments in $\mathrm{CO}_{2}$ assimilation rate and instantaneous water use efficiency mitigating the deleterious effects of salinity.

3. 'Gigante Amarelo' passion fruit plants fertilized with silicon dose of $300 \mathrm{~g} \mathrm{plant}^{-1}$ attained greater stem diameter and relative growth rate of stem diameter, in the period between 30 and 60 days after transplanting.

\section{Literature Cited}

Andrade, J. R. de; Medeiros, A. de S.; Maia Júnior, S. de O.; Rezende, L. de P.; Araújo Neto, J. C. de. Germination and morphophysiology of passion fruit seedlings under salt water irrigation. Pesquisa Agropecuária Tropical, v.48, p.229-236, 2018. https://doi. org/10.1590/1983-40632018v4852710

Arnon, D. I. Copper enzymes in isolated cloroplasts: Polyphenoloxidases in Beta vulgaris. Plant Physiology, v.24, p.1-15, 1949. https://doi. org/10.1104/pp.24.1.1

Ashraf, M.; Harris, P. J. C. Photosynthesis under stressful environments: An overview. Photosynthetica, v.51, p.163-190, 2013. https://doi. org/10.1007/s11099-013-0021-6

Ashraf, M.; Rahmatullah, M.; Afzal, R.; Ahmed, F.; Mujeeb, A.; Sarwar; Ali, L. Alleviation of deterimental effects of $\mathrm{NaCl}$ by silicion nutrition in salt-sensitive and salt-tolerant genotypes of sugarcane (Saccharum officinarum L.). Plant and Soil, v.326, p. 326-381, 2010. https://doi.org/10.1007/s11104-009-0019-9

Benincasa, M. M. P. Análise de crescimento de plantas: Noções básicas. Jaboticabal: FUNEP, 2003. 42p.

Bernardo, S; Soares, A. A.; Mantovani, E. C. Manual de irrigação. Viçosa: UFV, 2006. 625p.

Bezerra, J. D.; Pereira, W. E.; Silva, J. M. da; Raposo, R. W. C. Crescimento de dois genótipos de maracujazeiro-amarelo sob condições de salinidade. Revista Ceres, v.63, p.502-508, 2016. https://doi.org/10.1590/0034-737X201663040010

Campos, P. S.; Thi, A. T. P. Effect of abscisic acid pretreatment on membrane leakage and lipid composition of Vigna unguiculata leaf discs subject to osmotic stress. Plant Science, v.130, p.11-18, 1997. https://doi.org/10.1016/S0168-9452(97)00199-4

Cavalcanti, F. J. de A. Recomendações de adubação para o estado Pernambuco (2 a aproximação). 3.ed. Recife: Instituto Agronômico do Pernambuco - IPA, 2008, 212p.

Costa, B. N. S.; Costa, I. de J. S.; Dias, G. de M. G.; Assis, F. A. de; Pio, L. A. S; Soares, J. D. R.; Pasqual, M. Morpho-anatomical and physiological alterations of passion fruit fertilized with silicon. Pesquisa Agropecuária Brasileira, v.53, p.163-171, 2016. https:// doi.org/10.1590/s0100-204x2018000200004

Dias, N. da S.; Blanco, F. F.; Souza, E. R.; Ferreira, J. F.; Sousa Neto, O. N.; Queiroz, I. S. R. Tolerância das plantas à salinidade. Manejo da salinidade na agricultura: Estudos básicos e aplicados. Fortaleza: INCT Sal, 2016. Cap. 2, p. 151-161.

Freire, J. L. de O.; Dias, T. J.; Cavalcante, L. F.; Fernandes, P. D.; Neto Lima, A. J. de. Rendimento quântico e trocas gasosas em maracujazeiro amarelo sob salinidade hídrica, biofertilização e cobertura morta. Revista Ciência Agronômica, v.45, p.82-91, 2014. https://doi.org/10.1590/S1806-66902014000100011

Guerra, A. M. N. de M.; Rodrigues, F. A.; Lima, T. C.; Berger, P. G.; Barros, A. F.; Silva, Y. C. R. da. Capacidade fotossintética de plantas de algodoeiro infectadas por ramulose e supridas com silício. Bragantia, v.73, p.50-64, 2014. https://doi.org/10.1590/brag.2014.010
Hattori, T.; Inanaga, S.; Araki, H.; An, P.; Morita, S.; Luxová, M.; Lux, A. Application of silicon enhanced drought tolerance in Sorghum bicolor. Physiologia Plantarum, v.123, p. 459-466, 2005. https:// doi.org/10.1111/j.1399-3054.2005.00481.x

IBGE - Instituto Brasileiro de Geografia e Estatística. Censo Agro, Brasil, 2017. Available on: <https://censos.ibge.gov.br/ agro/2017/templates/censo_agro/resultadosagro/agricultura. html?localidade $=0 \&$ tema $=76346>$. Ac: Abr. 2020.

Jesus, E. G. de; Fatima, R. T. de; Guerrero, A. C.; Araújo, J. L. de; Brito, M. E. B. Growth and gas exchanges of arugula plants under silicon fertilization and water restriction. Revista Brasileira de Engenharia Agrícola e Ambiental, v.22, p.119-124, 2018. https:// doi.org/10.1590/1807-1929/agriambi.v22n2p119-124

Lima, G. S. de; Dias, A. S.; Gheyi, H. R.; Soares, L. A. dos A.; Nobre, R. G.; Sá, F. V. da S.; Paiva, E. P. de. Emergence, morpho-physiology and flowering of colored-fiber cotton (Gossypium hirsutum L.) submitted to different nitrogen levels and saline water stress irrigation. Australian Journal of Crop Science, v.11, p.897-905, 2017.

Marschner, H. Mineral nutrition of higher plants. San Diego: Academic Press, 1995. 889p.

Moussa, H. R.; Galad, M. A. R. Comparative response of salt tolerant and salt sensitive maize (Zea mays L.) cultivars to silicon. European Jounal of Academic Essays, v.2, p.1-5, 2015.

Munns, R.; Tester, M. Mechanisms of salinity tolerance. Annual Review of Plant Biology, v.59, p.651-681, 2008. https://doi. org/10.1146/annurev.arplant.59.032607.092911

Richards, L. A. Diagnosis and improvement of saline and alkali soils. Washington: USDA, Department of Agriculture, 1954. 160p. Agriculture Handbook No. 60

Rutschow, H. L.; Baskin, T. I.; Kramer, E. M. Regulation of solute flux through plasmodesmata in the root meristem. Plant Physiology, v.155, p.1817-1826, 2011. https://doi.org/10.1104/pp.110.168187

Santos, A. da S.; Araújo, R. H. C. R.; Nobre, R. G.; Sousa, V. F. de O. Rodrigues, M. H. B. S.; Formiga, J. A.; Gomes, F. A. L.; Santos, G. L. dos; Onias, E. A. Effect of hydrogen peroxide in the growth of yellow passion fruit seedlings under salinity stress. Journal of Agricultural Science, v.10, p.151-162, 2018. https://doi. org/10.5539/jas.v10n10p151

Santos, J. B. dos. Estudo das relações nitrogênio:potássio e cálcio:magnésio sobre o desenvolvimento vegetativo e produtivo do maracujazeiro amarelo. Areia: UFPB, 88p. 2001. Dissertação Mestrado

Silva, E. N. da; Ribeiro, R. V.; Ferreira-Silva, S. L.; Viégas, R. A.; Silveira, J. A. G. Salt stress induced damages on the photosynthesis of physic nut young plants. Scientia Agrícola, v.68, p.62-68, 2011. https://doi.org/10.1590/S0103-90162011000100010

Sousa, V. F. de O.; Costa, C. C.; Diniz, G. L.; Santos, J. B. dos; Bonfim, M. P.; Lopes, K. P. Growth and gas changes of melon seedlings submitted to water salinity. Revista Brasileira de Engenharia Agrícola e Ambiental, v.23, p.90-96, 2019. https:// doi.org/10.1590/1807-1929/agriambi.v23n2p90-96

Taiz, L.; Moller, E. Z. I. M.; Murphy, A. Fisiologia e desenvolvimento vegetal. 6.ed. Porto Alegre: Artmed, 2017. 918p.

Teixeira, P. C.; Donagemma, G. K.; Fontana, A.; Teixeira, W. G. (org.). Manual de métodos de análise de solo. 3. ed. Brasília, DF: Embrapa, 2017. 573p. 
Torres, E. C. de M.; Freire, J. L. M. O.; Freire, J. L. de O.; Bandeira, L. B.; Melo D. A. de; Silva, A. L. da. Biometria de mudas de cajueiro anão irrigadas com águas salinas e uso de atenuadores do estresse salino. Nativa, v.2, p.71-78, 2014. https://doi.org/10.14583/23187670.v02n02a03
Wanderley, J. A. C.; Azevedo, C. A. V. de; Brito, M. E. B.; Cordão, M. A.; Lima, R. F. de; Ferreira, F. N. Nitrogen fertilization to attenuate the damages caused by salinity on yellow passion fruit seedlings. Revista Brasileira de Engenharia Agrícola e Ambiental, v.22, p.541-546, 2018. https://doi.org/10.1590/1807-1929/agriambi.v22n8p541-546 